\title{
Isolation and characterization of polymorphic microsatellite loci in the swimming crab Portunus trituberculatus (Portunidae)
}

\author{
L.P. Ren', Y. Qin ${ }^{1}$, X.C. Li ${ }^{2}$, Y.N. Sun ${ }^{1}$ and R.X. Wang ${ }^{1}$ \\ ${ }^{1}$ Laboratory for Marine Living Resources and Molecular Engineering, \\ College of Marine Science, Zhejiang Ocean University, Zhoushan, China \\ ${ }^{2}$ Key Laboratory of East China Sea and Oceanic Fishery Resources Exploitation, \\ Ministry of Agriculture, Shanghai, China \\ Corresponding author. R.X. Wang \\ E-mail: wangrixin1123@126.com
}

Genet. Mol. Res. 12 (4): 5911-5915 (2013)

Received March 14, 2013

Accepted August 22, 2013

Published November 22, 2013

DOI http://dx.doi.org/10.4238/2013.November.22.19

\begin{abstract}
The Swimming crab Portunus trituberculatus (Portunidae) is an important economically food species. To provide molecular markers for $P$. trituberculatus, we isolated and characterized polymorphic microsatellite markers. We developed a 5'-anchored genomic library of P. trituberculatus DNA, and derived 45 positive clones. We designed 30 pairs of primers from the sequences of these clones, and 10 of which were polymorphic. The loci were screened in 31 P. trituberculatus individuals; the number of alleles ranged from 2 to 5 . The observed heterozygosity ranged from 0.20 to 0.49 and the expected heterozygosity ranged from 0.50 to 0.78 . The polymorphism information content per locus ranged from 0.37 to 0.75 . These polymorphic microsatellite markers may provide some useful information for the population genetic studies of swimming crab and other Portunus species.
\end{abstract}

Key words: Portunus trituberculatus; Microsatellite; Polymorphism; Molecular markers 


\section{INTRODUCTION}

The swimming crab, Portunus trituberculatus (Crustacea, Decapoda, Brachyura) is widely distributed in the coastal waters of Korea, Japan, China, and Southeast Asia (Dai et al., 1986). It inhabits estuaries and coastal waters and has a life span of about 1 to 3 years. Mating season of this species varies with geographic locations and the age of the individual (Dai, 1977; Xue et al., 1997), and they can spawn one to three times during each spawning season (Song et al., 1988). This swimming crab also has a capaticy for long distance dispersal species, the patterns of seasonal wind and water currents may influence the dispersal distance in this species (Shen and Liu, 1965).

In China, P. trituberculatus is not only a major edible crab species but also important for aquaculture (Yu et al., 2003a). Owing to its rapid growth and lucrative breeding, it has become an important breeding variety in the coastal areas of China. In addition, P. trituberculatus has been under intense fishing pressure gradually from 1950s across most of its Chinese distributions (Yu et al., 2003b, 2004). Due to the high commercial value of this species, $P$. trituberculatus supports a large crab fishery and aquaculture in China. In order to ensure the sustainability of this resource, artificial propagation has been promoted along the coastal waters of China (Sun, 1984). In general, the crab industry has relied on wild populations, both for harvest and to provide seed stock for aquaculture (Wu et al., 1996).

Mortality and life history parameters of this species had been widely studied (Yeon, 1999; Yeon et al., 1998). Knowledge of population genetic structure has become significant to the development of effective strategies for the fishing industry. In particular, determining levels of genetic diversity and histories of divergence has been significant for selective breeding in crab aquaculture (Imai et al., 1999). The population genetic diversity of this species was first surveyed in the coastal waters of Okayama Prefecture (Japan) by using mitochondrial DNA (mtDNA) RFLP markers. SSR markers are simple sequence repeats of one to six nucleotides, which are distributed widely and abundantly in the genome. These microsatellite markers have some unique characteristics, such as allelic co-dominance of alleles, high allelic diversity and the reproducibility of the relatively simple PCR-based screening methods; they have been considered to be one of the most powerful Mendelian markers (Jarne and Lagoda, 1996). As a result, these features have been advantageous for genetic mapping, quantitative trait locus association, population genetics and evolutionary studies (Hu et al., 2010; Xu et al., 2011). At present, microsatellite sequences have mainly been isolated by two ways: direct genomic sequencing or by generating DNA libraries by enrichment for the microsatellite sequences. The latter also has been achieved by two methods: the FIASCO method (Zane et al., 2002) and the 5'-anchored PCR method (Fisher et al., 1996). The anchored PCR method has been applied widely because of its high efficiency of isolation. In this study, we applied a 5 '-anchored method to develop the microsatellite loci for this species.

\section{MATERIAL AND METHODS}

\section{DNA samples}

P. trituberculatus individuals were collected from the Zhoushan coastal (Zhejiang, China). Total DNA was isolated from samples using the standard phenol-chloroform method 
(Sambrook and Russell, 2001). The quality of the isolated DNA was assessed by agarose gel electrophoresis and then stored at $-20^{\circ} \mathrm{C}$ for future use.

\section{Development of microsatellite library}

An enrichment library containing sequences with different microsatellite motifs was constructed by using a 5'-anchored PCR technique (Fisher et al., 1996). In brief, we selectively amplified by a single degenerate primer that anchores at the 5 '-end of a microsatellite motif by a sequence of seven degenerate bases ( $\mathrm{PCT}_{6}: 5^{\prime}-\mathrm{KKVRVRV}(\mathrm{CT})_{6}, \mathrm{~K}=\mathrm{G} / \mathrm{T}, \mathrm{V}=\mathrm{G} / \mathrm{C} / \mathrm{A}$, $\mathrm{R}=\mathrm{G} / \mathrm{A}$ ). The PCR amplification was carried out in a $25-\mu \mathrm{L}$ reaction volume, containing $1 \mathrm{X}$ PCR buffer, $0.2 \mathrm{mM}$ dNTPs, $0.2 \mu \mathrm{M}$ of the degenerate primer, and $1.5 \mathrm{U}$ Taq polymerase. The reaction conditions of the PCR were as follows: an initial denaturation of $95^{\circ} \mathrm{C}$ for $5 \mathrm{~min} ; 5$ cycles of $95^{\circ} \mathrm{C}$ for $30 \mathrm{~s}, 60^{\circ} \mathrm{C}$ for $30 \mathrm{~s}$, and an extension for $1 \mathrm{~min}$ at $72^{\circ} \mathrm{C}$; a further 30 cycles of $95^{\circ} \mathrm{C}$ for $30 \mathrm{~s}, 55^{\circ} \mathrm{C}$ for $30 \mathrm{~s}$, and a 1 -min extension at $72^{\circ} \mathrm{C}$; and a final extension step of $72^{\circ} \mathrm{C}$ for $10 \mathrm{~min}$. The PCR products were assessed on a $1.5 \%$ agarose gel. Amplicons of $300-$ $800 \mathrm{bp}$ were extracted from the gel, purified and were then cloned into pMD19-T plasmid vectors (TaKaRa) and used to transform competent Escherichia coli DH5a cells. Positive clones, which appeared as single distinct bands on agarose gels, were selectively amplified by using the M13-F/R universal primers. Finally, the sequences were detected on the ABI PRISM 3730 Genetic Analyzer. Thirty pairs of specific primers were designed using the Primer Premier 5.0 software (PREMIER Biosoft International, USA).

\section{Microsatellite genotyping}

Microsatellite loci were characterized based on all the 31 P. trituberculatus different individuals. PCR amplifications were carried out with a $15-\mu \mathrm{L}$ reaction volume containing 50 ng template DNA, $0.2 \mu \mathrm{M}$ primer (each), $1 \mathrm{U}$ Taq polymerase (Tiangen), $0.15 \mathrm{mM}$ of each dNTP, and $1.5 \mu \mathrm{L}$ 10X PCR buffer. The reaction conditions of the PCR were as follows: $95^{\circ} \mathrm{C}$ for $5 \mathrm{~min} ; 35$ cycles of $95^{\circ} \mathrm{C}$ for $30 \mathrm{~s}$, annealing temperature for $30 \mathrm{~s}$, and $72^{\circ} \mathrm{C}$ for $40 \mathrm{~s}$ and a final extension at $72^{\circ} \mathrm{C}$ for $10 \mathrm{~min}$. The amplified products were denatured for $8 \mathrm{~min}$ at $95^{\circ} \mathrm{C}$, then separated on $6 \%$ denaturing polyacrylamide gels (19:1 acrylamide:bis-acrylamide) and visualized by silver staining. The allele sizes were calibrated using a pBR322 DNA/MspI molecular weight marker (Tiangen).

The Popgene 32 program was used to determine the number of alleles per locus, the effective number of alleles, the expected $\left(H_{\mathrm{E}}\right)$ and observed $\left(H_{\mathrm{O}}\right)$ heterozygosities, and to test for departures from Hardy-Weinberg equilibrium (HWE) (Yeh and Boyle, 1997). Arlequin 3.11 was used to test for genotypic linkage disequilibrium between the loci (Excoffier and Lischer, 2010). All P values were corrected for multiple testing using a Bonferroni's correction (Rice, 1989).

\section{RESULTS AND DISCUSSION}

Among 30 pairs of microsatellite primers designed, 26 pairs were successfully amplified and $10(38.5 \%)$ of these loci were found to be polymorphic. Details of these polymorphic microsatellite loci in P. trituberculatus and their variability are summarized in Table 1 . The 
number of alleles found at each locus ranged from 2 to 5 , with a mean of 3.50. $H_{\mathrm{O}}$ and $H_{\mathrm{E}}$ ranged from $0.20-0.49$ and from $0.50-0.78$, respectively. The PIC values of the microsatellites ranged from 0.37 to 0.75 and all loci were highly polymorphic ( $\mathrm{PIC}>0.5)$.

\begin{tabular}{|c|c|c|c|c|c|c|c|c|c|c|c|}
\hline Locus & GenBank & Primer sequence $\left(5^{\prime}-3^{\prime}\right)$ & $\begin{array}{r}\mathrm{Tm} \\
\left({ }^{\circ} \mathrm{C}\right) \\
\end{array}$ & Repeat motif & $\begin{array}{l}\text { Size range } \\
\text { (bp) }\end{array}$ & $N_{\mathrm{A}}$ & $N_{\mathrm{E}}$ & $\begin{array}{l}\text { HWE } \\
(\mathrm{P})\end{array}$ & PIC & Null & $H_{\mathrm{O}} / H_{\mathrm{E}}$ \\
\hline Potr-11 & KC470116 & $\begin{array}{l}\text { F: TCATCACCACCATTAGTACG } \\
\text { R: CTCCCTCCTTCCTTTATCCC }\end{array}$ & 55 & $(\mathrm{GT})_{33}$ & $110-123$ & 4 & 3.90 & $0.00 *$ & 0.67 & 0 & $0.24 / 0.74$ \\
\hline Potr-14 & KC470117 & $\begin{array}{l}\text { F: GCTCTCTCTCTCTGGAACACTT } \\
\text { R: GCTGCTGCCGCTCATATCAACC }\end{array}$ & 55 & $(\mathrm{CT})_{6}$ & $118-123$ & 2 & 2.00 & 0.23 & 0.37 & 0 & $0.49 / 0.50$ \\
\hline Potr-10 & KC470114 & $\begin{array}{l}\text { F: AACGACAACAATGATCCCTT } \\
\text { R: CAGTTAGTTATTTGATTTGCTTTA }\end{array}$ & 52 & $(\mathrm{CT})_{12}$ & $149-158$ & 3 & 2.85 & 0.25 & 0.57 & 0 & $0.34 / 0.65$ \\
\hline Potr-15 & KC470118 & $\begin{array}{l}\text { F: GCTCTCTCTCTCTGGAACACTT } \\
\text { R: CATACGGCAACAGTCCACCTCT }\end{array}$ & 56 & $(\mathrm{CT})_{6}$ & $104-110$ & 3 & 2.87 & 0.02 & 0.58 & 0 & $0.33 / 0.65$ \\
\hline Potr-9 & KC470114 & $\begin{array}{l}\text { F: GGAGGAACTCTCTCTCTCTGTG } \\
\text { R: TCTTTAGGTGTCATTTACTTGT }\end{array}$ & 46 & $(\mathrm{CT})_{6}(\mathrm{GT})_{35}(\mathrm{AG})_{7}$ & $110-123$ & 4 & 3.66 & 0.03 & 0.68 & 1 & $0.25 / 0.73$ \\
\hline Potr-27 & KC470122 & $\begin{array}{l}\text { F: TACAGTAAAATACAGCAACGAC } \\
\text { R: AGCTAAGAATAAGAATCCTCCG }\end{array}$ & 58 & $(\mathrm{GT})_{7}(\mathrm{GA})_{41}$ & $147-155$ & 3 & 2.82 & 0.98 & 0.57 & 0 & $0.34 / 0.65$ \\
\hline Potr-26 & KC470121 & $\begin{array}{l}\text { F: TACAGTAAAATACAGCAACGAC } \\
\text { R: TAAGAATAAGAATCCTCCGCAC }\end{array}$ & 58 & $(\mathrm{GT})_{7}(\mathrm{GA})_{41}$ & $113-117$ & 3 & 2.93 & 0.79 & 0.58 & 0 & $0.33 / 0.66$ \\
\hline Potr-29 & KC470123 & $\begin{array}{l}\text { F: GAAACTAACCAACTTACCTACAT } \\
\text { R: TTCTTTAGGTGTCATTTACTTGT }\end{array}$ & 58 & $(\mathrm{CT})_{6}(\mathrm{GT})_{35}(\mathrm{AG})_{7}$ & $145-157$ & 5 & 4.57 & 0.30 & 0.75 & 0 & $0.20 / 0.78$ \\
\hline Potr-18 & KC470119 & $\begin{array}{l}\text { F: CACTAGGAAAATAATAAGCATAA } \\
\text { R: GGAACTCTCTCTCTCTGTTGGGA }\end{array}$ & 58 & $(\mathrm{CT})_{6}$ & $115-123$ & 3 & 2.93 & $0.00^{*}$ & 0.58 & 0 & $0.33 / 0.66$ \\
\hline Potr-25 & KC470120 & $\begin{array}{l}\text { F: TACAGTAAAATACAGCAACGAC } \\
\text { R: CAAGCTAAGAATAAGAATCCTC }\end{array}$ & 56 & $(\mathrm{GT})_{7}(\mathrm{GA})_{41}$ & $133-151$ & 5 & 4.24 & 0.23 & 0.73 & 0 & $0.22 / 0.76$ \\
\hline
\end{tabular}

$N_{\mathrm{A}}=$ number of alleles; $N_{\mathrm{E}}=$ effective number of alleles; $H_{\mathrm{E}} / H_{\mathrm{O}}=$ expected and observed heterozygosities; $\mathrm{HWE}=$ Hardy-Weinberg equilibrium and GenBank accession number of 10 polymorphic microsatellite loci. *Significant deviation from HWE $(\mathrm{P}<0.004)$.

Among the 10 novel loci, 2 loci (potr-11 and potr-18) were found to deviate significantly from HWE in the sampled population, after Bonferroni's correction. The locus (potr-9) was found to exhibit null alleles. There were no stuttering errors and no evidence of allelic dropout in any of the loci analyzed by Micro-Checker (Van Oosterhout et al., 2004).

The 10 polymorphic microsatellite loci developed in this study will assist studies of genetic variation, population structure, and conservation genetics and the molecular-assisted selective breeding of this species of swimming crab.

\section{ACKNOWLEDGMENTS}

Research supported by the Important Science and Technology Specific Projects of Zhejiang Province (\#2011C12011) and the Open Project of Key Laboratory of East China Sea \& Oceanic Fishery Resources Exploitation and Utilization, Ministry of Agriculture (\#K201207).

\section{REFERENCES}

Dai AY (1977). Primary investigation on the fishery biology of the Portunus trituberculatus. Mar. Fish. 25: 136-141. Dai AY, Yang SL and Song YZ (1986). Marine crabs in China Sea. Marine Publishing Company, Beijing, 194-196.

Excoffier L and Lischer HE (2010). Arlequin suite ver 3.5: a new series of programs to perform population genetics analyses under Linux and Windows. Mol. Ecol. Resour. 10: 564-567.

Fisher PJ, Gardner RC and Richardson TE (1996). Single locus microsatellites isolated using 5' anchored PCR. Nucleic Acids Res. 24: 4369-4371. 
Hu JB, Zhou XY and Li JW (2010). Development of novel EST-SSR markers for cucumber (Cucumis sativus) and their transferability to related species. Sci. Hortic. 125: 534-538.

Imai H, Fujii Y, Karakawa J, Yamamoto S, et al. (1999). Analysis of the population structure of the swimming crab, Portunus trituberculatus in the coastal waters of Okayama Prefecture, by RFLPs in the whole region of mitochondrial DNA. Fish. Sci. 65: 655-656.

Jarne P and Lagoda PJ (1996). Microsatellites, from molecules to populations and back. Trends Ecol. Evol. 11: 424-429.

Rice WE (1989). Analyzing tables of statistical tests. Evolution 43: 223-225.

Sambrook J and Russell DW (2001). Molecular Cloning: A Laboratory Manual. 3rd edn. Cold Spring Harbor Laboratory Press, New York.

Shen JR and Liu RY (1965). Shrimps and Crabs in China. Science Popularization Press, Beijing, 23.

Song HT, Ding YP and Xu YJ (1988). The research on the reproduction behavior of the Portunus trituberculatus in the northern coast water of Zhejiang Province. J. Zhejiang Ocean Univ. 7: 39-46.

Sun YM (1984). Larvae development of the swimming crab, Portunus trituberculatus. J. Fish. China 8: 219-226.

Van Oosterhout C, Hutchinson WF, Wills DPM and Shipley P (2004). MICRO-CHECKER: software for identifying and correcting genotyping errors in microsatellite data. Mol. Ecol. Notes 4: 535-538.

Wu CW, Yu SC and Lv YL (1996). Fishery Techniques of the Swimming Crab Portunus Trituberculatus. Shanghai Science and Technology Press, Shanghai, 28-31.

Xu T, Sun D, Sun Y and Wang R (2011). Development of 30 Novel Polymorphic Expressed Sequence Tags (EST)Derived Microsatellite Markers for the Miiuy Croaker, Miichthys miiuy. Int. J. Mol. Sci. 12: 4021-4026.

Xue JZ, Du NS and Nai W (1997). The researches on the Portunus trituberculatus in China. Donghai Mar. Sci. 15: 60-64.

Yeh FC and Boyle TJB (1997). Population genetic analysis of co-dominant and dominant markers and quantitative traits. Belg. J. Bot. 129: 157.

Yeon IJ (1999). The reproductive biology of blue crab, Portunus trituberculatus (Miers), in the East China Sea. Bull. Nat. Fish. Res. Dev. Inst. Korea 56: 1-12.

Yeon IJ, Kang YJ and Zhang CI (1998). Growth and mortality of blue crab, Portunus trituberculatus in the East China Sea. Korean Soc. Fish. Res. 1: 104-114.

Yu CG, Song HT and Yao GZ (2003a). Geographical distribution and faunal analysis of crab resources in the East China Sea. J. Zhejiang Ocean Univ. 22: 108-113.

Yu CG, Song HT, Yao GZ and Shen XY (2003b). Study on rational utilization of crab resources in the inshore water of Zhejiang. Maine Fish. 25: 136-141.

Yu CG, Song HT and Yao GZ (2004). Assessment of the crab stock biomass in the continental shelf waters of the East China Sea. J. Fish. Chin. 28: 41-46.

Zane L, Bargelloni L and Patarnello T (2002). Strategies for microsatellite isolation: a review. Mol. Ecol. 11: 1-16. 